\title{
The Effects of Workload and Work Environment on Local Police Performance: A Test of Work-related Stress' Mediating Effect
}

\author{
Arip Marianto \\ Faculty of Economics, Universitas Terbuka, Indonesia \\ Email:mariantoarip@gmail.com
}

\begin{abstract}
:
This research aims to analyze the influence of workload and work environment, mediated by work-related stress, on local police officers' performance. The population of this research was police officers of the Yapen Island Regency's Local Police, Papua region. The Slovin formula was used to determine the number of samples, and as many as 169 respondents were selected using a simple random sampling technique. A five-point Likert scale questionnaire was used as a research instrument. The SPSS Statistics was used to analyze the data. The analytical method used was descriptive analysis, validity and reliability tests, classical assumption tests, regression analysis, and mediation analysis using PROCESS macro by Hayes. The results showed that workload and work environment had a significant favorable influence on workrelated stress. It also revealed that workload and work environment had a significant favorable influence on performance. Besides, work-related stress had a significant negative influence on performance. Work-related stress could mediate the relationship between workload and performance, while the relationship between work environment and performance could not be mediated by work-related stress. It implies that workload should be the improvement priority in designing the achievable performance target.
\end{abstract}

\section{Keywords:}

workload; work environment; work-related stress

\section{Introduction}

As the front guard in law enforcement, the police institution in Indonesia needs maximum support from its human resources both in quantity and quality. Currently, the Indonesian police force is the fifth largest globally, with around 400,000 personnel and a ratio between police officers and a population of 1:600 (Davies et al., 2016). Papua Province is the province under the tightest surveillance globally, with a ratio between the police officer and the population of 1:100 (Davies et al., 2016). The police institution is one of the state institutions as the front guard for public security with quite formidable tasks that tend to be done individually by police officers, who are required to be able to make decisions individually in the face of reality (Huff, 2020; Abdiyanto \& Warokka, 2015).

The Yapen Regency's local police agency is one of the ones in the Papua region, which oversees six police precincts. Those six police precincts' offices have different distances from the Yapen Regency's local police agency headquarter. Some are 10 minutes away by motorbike or car, while others are 8-10 hours by boat. With this geographical condition, working as a police officer, especially in a distant region, requires extra energy. The demand to always be well disciplined and obey the orders of superiors is not an easy matter, and it can lead to excessive work-related stress (Arafat et al., 2012). 
Further, human resources are one of the primary resources directly related to achieving organizational goals (Ackah, 2015). Meanwhile, the Yapen Regency's local police agency has not performed well. This fact can be seen from the letter of the Papua Regional Police Chief Number B/2854/XII/REN.5.1./2019/ITWASDA, dated December 30, 2019, stated that the Yapen Regency's local police agency received a score of 64.14. This score made the Yapen Regency's local police agency obtain the CC category. This result certainly needs more attention from stakeholders in the Yapen Regency's local police agency.

The low-performance score of the Yapen Regency's local police agency is probably due to the non-ideal workload. Based on pre-observations in this study, officers of the Yapen Regency's local police agency are divided into three teams. Each team serves as duty officers for $1 \mathrm{x} 12$ hours. In a month, officers have to work for 120 hours. Besides, if an officer becomes a reserve police officer at least ten times a month, it means the officer has an additional 80 hours of work to do. So, in a month, there are officers who have 200 hours of work. Apart from long working hours, police officers assigned to the criminal investigation unit, the drug law enforcement unit, and the intelligence unit also have the responsibility to resolve certain cases. This condition, of course, can cause high levels of work-related stress (Arnetz et al., 2013). And it also applies to police officers who are assigned to the Yapen Regency's local police agency.

The workload for officers at the Yapen Regency's local police agency is quite heavy. It was indicated from an interview with the Head of the Human Resources Division of the Yapen Regency's local police agency, who stated that his position alone had many workloads, which could cause work stress. In addition to causing work stress, this workload can lead to underperformance (Im, 2009; Oron-Gilad et al., 2008; Sharma, 2015). The results of Huyghebaert et al. (2018) proved that workload had a negative influence on performance. Research conducted by Ngatimun et al. (2019) also found that workload negatively influenced performance. Meanwhile, research conducted by Susiarty et al. (2019) found no significant correlation between workload and performance.

There are two research questions in this study: [a] do workload, work environment, and work stress affect performance? [b] does work-related stress mediate those antecedents' effect on performance? Therefore, this research aims to study and analyze the influence of workload and work environment on performance, mediated by work stress, at the Yapen Regency's local police agency.

\section{Review of Literatures}

\subsection{Performance}

Performance is the key to measure the success of an organization (Waal, 2018). Cherrington (1989) defines performance as the concept of success or organizational effectiveness and as an indication of how organizations can effectively achieve their goals. In general, performance is related to the ability of employees to do their job well or not (Schmidt, 2002). Individual performance is defined as things done by members of the organization, such as actions that contribute to organizational goals (Campbell and Wiernik, 2015). According to Jones (2019), several factors that influence individual performance are job demands, training and development, and behavior. Performance is the estuary and organizational culture is the base, while work motivation, job satisfaction is between the beginning and end (Arif et al, 2019). Performance is about doing work and the results achieved from the job. Performance is about what is done and how to do it. Performance is the result of work that has a strong 
relationship with the organization's strategic goals, customer satisfaction and economic contribution (Wibowo in Saragih and Ananda, 2019).

\subsection{Workload}

The problem that often arises is the influence of workload on the decline in employee performance. It is due to the targets to be achieved, redundant tasks and responsibilities, limited time, and skills mismatch, which result in work-related stress (Murali et al., 2017). AlMohannadi and Capel (2007) stated that if the workload increases, the work-related stress will also increase. Previous research conducted by Arifi et al. (2019) and Sinambela (2020)) found a positive and significant correlation between workload and work-related stress. Therefore, referring to the previous empirical findings, the first proposed hypothesis is:

$\mathrm{H}_{1}$ : Workload has a positive and significant influence on police officers' work-related stress.

A heavy workload can cause a decline in performance (Fan \& Smith, 2017), indicating that an employee's workload can have an impact on their performance (Ackah, 2015). The higher the workload is, especially when the workload creates difficulties for the employee to complete it, the lower the employee's performance will be (Munandar et al., 2018). Previous research conducted by Huyghebaert et al. (2018) and Ngatimun et al. (2019) found that workload negatively influenced performance. Therefore, the following proposed hypothesis is: $\mathrm{H}_{2}$ : Workload has a negative and significant influence on the performance of officers.

\subsection{Work Environment}

A monotonous work environment will result in workers being less maximal in doing their activities and can increase work-related stress (Putra \& Putri, 2020). Work-related stress, concerning the physical work environment, is a feeling of comfort or discomfort with employees working in that location (Vischer, 2007). Previous research conducted by Desa et al. (2018), Hornsby et al. (2009), and Manaf et al. (2019) found a significant negative relationship between work environment and work-related stress. Therefore, the third proposed hypothesis is:

$\mathrm{H}_{3}$ : Work environment has a negative and significant influence on police officers' work-related stress.

Also, Chen (2009) and Mathews and Khann (2013) showed that the work environment affects performance. They discovered a significant relationship between work environment and employee performance. The work environment is closely related to employee job involvement and job satisfaction, leading to better employee performance (Vest et al., 2000). If the work environment created in the organization is conducive or pleasant, it will provide positive support for employees at work (Hartinah et al., 2020). Previous research conducted by Handayani (2019), Rorong (2016) discovered a positive and significant correlation between work environment and performance. Thus, the fourth proposed hypothesis is:

$\mathrm{H}_{4}$ : The work environment has a positive and significant influence on police officers' performance.

\subsection{Work-related Stress}

Research conducted by Ahmed and Ramzan (2013) discovered that work-related stress in a company had a negative and significant influence on performance. When employees experience work-related stress, the performance they want to achieve will decline. This research was later supported by Alkubaisi (2015), Ngatimun et al. (2019), and Shahriari et al. (2013), who found a negative and significant relationship between occupational stress and performance. Therefore, the fifth proposed hypothesis is: 
$\mathrm{H}_{5}$ : Work-related stress has a positive and significant influence on police officers' performance.

Research conducted by Shabbir and Naqvi (2017), and Susiarty et al. (2019) proved that work stress could mediate the relationship between workload and performance. According to Murali et al. (2017), the problem that often arises is the influence of workload on declining employee performance, which is due to the targets to be achieved, redundant tasks and responsibilities, limited time, and skills mismatch that result in work-related stress. The excessive workload can result in a high level of work-related stress and ultimately affect the performance of members of an organization. Thus, the sixth proposed hypothesis is:

$\mathrm{H}_{6}$ : Work-related stress mediates the relationship between workload and the police officers' performance.

Furthermore, the research results conducted by Susiarty et al. (2019) and Khuong and Yen (2016) proved that work-related stress could mediate the relationship between work environment and performance. Unfavorable workplace conditions, such as noisy workplaces with inadequate lighting, poor air quality, and other ergonomic problems, can cause employees to be unable to work correctly in the workplace (Dalbokova \& Krzyzanowski, 2002). The higher the dissatisfaction with work factors and the level of work-related stress is, the lower the employee performance becomes (Khuong \& Yen, 2016). Thus, the seventh proposed hypothesis in this research is:

$\mathrm{H}_{7}$ : Work-related stress mediates the relationship between the work environment and the police officers' performance.

The seven proposed hypotheses are summarized in the following research model:
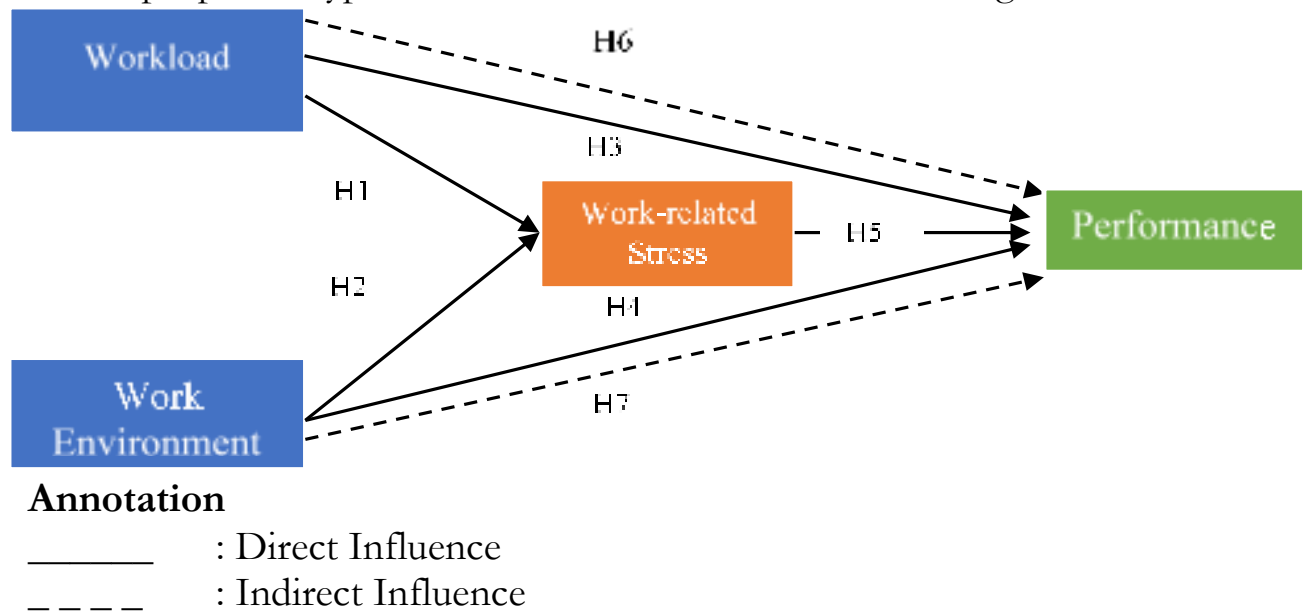

Figure 1. Research Model

\section{Research Methods}

This research is associative research that aims to determine the relationship between two or more variables. The population in this research was 287 officers of the Yapen Regency's local police agency. Furthermore, the Slovin formula was used to determine the number of samples, and as many as 169 respondents were obtained using a simple random sampling technique. It is called simple because elements of the population did not need to be divided into several subsamples, which became the data analysis unit. A 5-point Likert scale questionnaire was used as the research instrument. Apart from questionnaires, observations and interviews were also conducted to collect data. 


\section{Results and Discussion}

Respondents in this research were 169 police officers at Yapen Regency's local police headquarter. The characteristics of the respondents are as follows.

Table 1. Description of Respondent Characteristics

\begin{tabular}{|c|c|c|c|}
\hline Category & Alternative Response & $\begin{array}{c}\text { Number of } \\
\text { Respondents }\end{array}$ & $\begin{array}{c}\text { Percentage } \\
(\%)\end{array}$ \\
\hline \multirow{2}{*}{ Sex } & Male & 156 & $92.3 \%$ \\
\hline & Female & 13 & $7.7 \%$ \\
\hline \multirow{8}{*}{ Age } & 21-25 Years Old & 31 & $18.3 \%$ \\
\hline & 26-30 Years Old & 29 & $17.2 \%$ \\
\hline & 31-35 Years Old & 47 & $27.8 \%$ \\
\hline & 36-40 Years Old & 30 & $17.8 \%$ \\
\hline & 41-45 Years Old & 15 & $8.9 \%$ \\
\hline & 46-50 Years Old & 8 & $4.7 \%$ \\
\hline & 51-55 Years Old & 2 & $1.2 \%$ \\
\hline & Above 56 Years Old & 7 & $4.1 \%$ \\
\hline \multirow{3}{*}{ Education Level } & High School/Vocational High School & 140 & $82.8 \%$ \\
\hline & Assoctiate's Degree & 1 & $0.6 \%$ \\
\hline & Bachelor's Degree & 28 & $16.6 \% \%$ \\
\hline \multirow{3}{*}{ Rank } & Field Officer & 1 & $0.6 \%$ \\
\hline & Subaltern Officer & 18 & $10.6 \%$ \\
\hline & Non-commissioned Officer & 150 & $88.8 \%$ \\
\hline \multirow{17}{*}{ Unit } & Intelligence and Security & 11 & $6.5 \%$ \\
\hline & Patrol & 28 & $16.6 \%$ \\
\hline & Water and Air Police Corps & 6 & $3.6 \%$ \\
\hline & Planning & 6 & $3.6 \%$ \\
\hline & Financial & 3 & $1.8 \%$ \\
\hline & Supervision & 2 & $1.2 \%$ \\
\hline & Criminal Investigation & 30 & $17.8 \%$ \\
\hline & Traffic Enforcement & 20 & $11.8 \%$ \\
\hline & Detainees \& Evidence & 3 & $1.8 \%$ \\
\hline & Resources & 10 & $5.9 \%$ \\
\hline & General Affairs & 6 & $3.6 \%$ \\
\hline & Narcotics & 6 & $3.6 \%$ \\
\hline & Community \& Society Development & 8 & $4.7 \%$ \\
\hline & Operational Support & 8 & $4.7 \%$ \\
\hline & Profession and Internal Security & 9 & $5.3 \%$ \\
\hline & Information Technology & 1 & $0.6 \%$ \\
\hline & Others & 12 & $7.1 \%$ \\
\hline
\end{tabular}

The Respondent Characteristics Description showed that most respondents were male $(92.3 \%)$ and in the age range $31-35$ years $(27.8 \%)$ and had high school or vocational high school diploma (82.8\%). Most of the respondents were non-commissioned officers $(88.8 \%)$ and from the criminal investigation unit $(17.8 \%)$. 
Before the questionnaires were distributed to all respondents, a pilot test was conducted on 30 respondents. The results of the validity test showed that several invalid statements could not be used as research instruments. The invalid statements were one statement from the workload variable (X1.8), 11 statements from the work environment variable (X2.1, X2.3, X2.4, X2.6, X2.14, X2.15, X2 .17, X2.20, X2.21, X2.23, and X2.25), and three statements from work-related stress variable (Y1.1, Y1.2, and Y1.3).

After the data were obtained by distributing questionnaires to all respondents, the conditions and characteristics of the respondents' responses were described by descriptive analysis. The results of the analysis showed the respondents' tendency for each variable used in this research. Then, the respondents' responses were categorized by an interval scale, which is simply the highest score, minus the lowest score, divided by five so that the interval was 0.80. With an interval of 0.80, the categorization system was as follows: 1.00-1.80 (very low); 1.81-2.60 (low); 2.61-3.40 (moderate); 3,41-4,20 (high); and 4.21-5.00 (very high) (Sugiyono, 2013).

Table 2. Results of the Descriptive Analysis of Respondents' Responses

\begin{tabular}{|c|c|c|c|c|c|c|c|c|c|}
\hline \multirow{2}{*}{\multicolumn{2}{|c|}{ Items }} & \multicolumn{5}{|c|}{ Alternative Opinions } & \multirow{3}{*}{ Total } & \multirow{3}{*}{ Mean } & \multirow{3}{*}{ Category } \\
\hline & & D & SD & SA & A & EA & & & \\
\hline & 1 & 2 & 3 & 4 & 5 & & & \\
\hline $\mathrm{X} 1.3$ & $\begin{array}{l}\text { I have numerous duties in the } \\
\text { past month. }\end{array}$ & 7 & 40 & 44 & 50 & 28 & 169 & 3.54 & High \\
\hline $\mathrm{X} 1.4$ & $\begin{array}{l}\text { I have to complete many duties } \\
\text { in the past month. }\end{array}$ & 8 & 39 & 32 & 65 & 25 & 169 & 2.91 & Moderate \\
\hline $\mathrm{X} 1.5$ & $\begin{array}{l}\text { The duties assigned to me are not } \\
\text { outlined in my job description. }\end{array}$ & 37 & 59 & 22 & 31 & 20 & 169 & 3.31 & Moderate \\
\hline X1.6 & $\begin{array}{l}\text { Most of the duties I carry are the } \\
\text { delegation of duties of other } \\
\text { officers. }\end{array}$ & 38 & 70 & 14 & 25 & 22 & 169 & 3.36 & Moderate \\
\hline $\mathrm{X} 1.7$ & $\begin{array}{l}\text { It takes me a lot of time to } \\
\text { complete my duties. }\end{array}$ & 11 & 25 & 36 & 68 & 29 & 169 & 2.63 & Moderate \\
\hline $\mathrm{X} 1.9$ & $\begin{array}{l}\text { I feel that the responsibility that } \\
\text { is put on me is too heavy. }\end{array}$ & 20 & 58 & 41 & 36 & 14 & 169 & 2.54 & Low \\
\hline $\mathrm{X} 1.10$ & $\begin{array}{l}\text { My responsibilities make me have } \\
\text { sleeping difficulty. }\end{array}$ & 34 & 62 & 30 & 25 & 18 & 169 & 3.47 & High \\
\hline $\mathrm{X} 1.11$ & $\begin{array}{l}\text { I have little time for my family } \\
\text { because I have to do my duties. }\end{array}$ & 18 & 50 & 33 & 45 & 23 & 169 & 2.80 & Moderate \\
\hline $\mathrm{X} 1.12$ & Working hours drain my energy. & 21 & 36 & 41 & 50 & 21 & 169 & 2.59 & Low \\
\hline $\mathrm{X} 1.13$ & $\begin{array}{l}\text { I have heavier duties than my } \\
\text { colleagues do. }\end{array}$ & 27 & 66 & 25 & 29 & 22 & 169 & 3.03 & Moderate \\
\hline $\mathrm{X} 1.14$ & $\begin{array}{l}\text { I often have additional duties } \\
\text { outside of what I am responsible } \\
\text { for. }\end{array}$ & 24 & 59 & 23 & 38 & 25 & 169 & 3.08 & Moderate \\
\hline \multicolumn{7}{|c|}{ Average } & & 2.99 & Moderate \\
\hline $\mathrm{X} 2.2$ & $\begin{array}{l}\text { The air temperature at the } \\
\text { workplace supports me in doing } \\
\text { my work. }\end{array}$ & 1 & 3 & 13 & 103 & 49 & 169 & 4.16 & High \\
\hline $\mathrm{X} 2.5$ & $\begin{array}{l}\text { The workspace has sufficient } \\
\text { lighting. }\end{array}$ & 4 & 3 & 9 & 104 & 49 & 169 & 4.13 & High \\
\hline $\mathrm{X} 2.7$ & $\begin{array}{l}\text { The air temperature at the } \\
\text { workplace is cool. }\end{array}$ & 13 & 23 & 11 & 77 & 45 & 169 & 3.70 & High \\
\hline $\mathrm{X} 2.8$ & $\begin{array}{l}\text { I work in an environment with } \\
\text { good air quality. }\end{array}$ & 5 & 11 & 22 & 69 & 47 & 169 & 3.75 & High \\
\hline $\mathrm{X} 2.9$ & I work in an appropriate space. & 5 & 77 & 25 & 73 & 41 & 169 & 3.71 & High \\
\hline $\mathrm{X} 2.10$ & My workspace is not cramped. & 9 & 27 & 26 & 79 & 228 & 169 & 3.53 & High \\
\hline
\end{tabular}




\begin{tabular}{|c|c|c|c|c|c|c|c|c|c|}
\hline $\mathrm{X} 2.11$ & $\begin{array}{l}\text { The workspace enables me to } \\
\text { interact with other officers. }\end{array}$ & 4 & 11 & 23 & 87 & 62 & 169 & 3.92 & High \\
\hline $\mathrm{X} 2.12$ & The workplace is well organized. & 1 & 19 & 24 & 87 & 38 & 169 & 3.84 & High \\
\hline $\mathrm{X} 2.13$ & I have my workspace. & 26 & 39 & 25 & 57 & 22 & 169 & 3.06 & Moderate \\
\hline $\mathrm{X} 2.16$ & $\begin{array}{l}\text { Every certain period, auditors } \\
\text { come to check the work results. }\end{array}$ & 4 & 5 & 20 & 95 & 45 & 169 & 4.02 & High \\
\hline $\mathrm{X} 2.18$ & $\begin{array}{l}\text { The work atmosphere is very } \\
\text { conducive to completing duties. }\end{array}$ & 2 & 4 & 11 & 96 & 56 & 169 & 4.18 & High \\
\hline $\mathrm{X} 2.19$ & $\begin{array}{l}\text { The reward system is enforced } \\
\text { according to the rules. }\end{array}$ & 3 & 20 & 24 & 73 & 48 & 169 & 3.86 & High \\
\hline $\mathrm{X} 2.22$ & $\begin{array}{l}\text { We have nothing to fear in doing } \\
\text { our duties. }\end{array}$ & 2 & 9 & 13 & 86 & 59 & 169 & 4.13 & High \\
\hline $\mathrm{X} 2.24$ & $\begin{array}{l}\text { The officers support each other } \\
\text { in doing their duties. }\end{array}$ & 1 & 8 & 24 & 77 & 59 & 169 & 4.09 & High \\
\hline \multicolumn{8}{|c|}{ Average } & 3.86 & High \\
\hline M.4 & $\begin{array}{l}\text { I hope to transfer to other } \\
\text { working areas. }\end{array}$ & 51 & 53 & 28 & 24 & 13 & 169 & 2.38 & Low \\
\hline M.5 & I prefer to work individually. & 54 & 71 & 27 & 14 & 3 & 169 & 2.06 & Low \\
\hline M.6 & $\begin{array}{l}\text { I rarely spend time with my } \\
\text { colleagues. }\end{array}$ & 82 & 61 & 19 & 6 & 1 & 169 & 1.72 & Low \\
\hline M.7 & I find it difficult to sleep. & 66 & 60 & 31 & 11 & 1 & 169 & 1.94 & Low \\
\hline M.8 & $\begin{array}{l}\text { Concentration at work keep me } \\
\text { from sleeping well. }\end{array}$ & 54 & 65 & 34 & 12 & 4 & 169 & 2.09 & Low \\
\hline M.9 & $\begin{array}{l}\text { I cannot enjoy my duty because I } \\
\text { have to finish it quickly. }\end{array}$ & 46 & 64 & 40 & 18 & 1 & 169 & 2.20 & Low \\
\hline M.10 & $\begin{array}{l}\text { If I take it easy, my duty will not } \\
\text { be completed on time. }\end{array}$ & 11 & 23 & 43 & 70 & 22 & 169 & 3.41 & High \\
\hline M.11 & $\begin{array}{l}\text { I am worried that I will not be } \\
\text { able to complete my duties } \\
\text { correctly. }\end{array}$ & 29 & 50 & 43 & 35 & 12 & 169 & 2.71 & Moderate \\
\hline M.12 & $\begin{array}{l}\text { I am always vigilant during } \\
\text { fieldwork. }\end{array}$ & 6 & 21 & 38 & 67 & 37 & 169 & 3.64 & High \\
\hline M.13 & $\begin{array}{l}\text { I feel nervous when I am } \\
\text { assigned to a duty I have never } \\
\text { done before. }\end{array}$ & 26 & 43 & 60 & 34 & 6 & 169 & 2.71 & Moderate \\
\hline M.14 & $\begin{array}{l}\text { I cannot relax in the last few } \\
\text { months. }\end{array}$ & 45 & 61 & 45 & 11 & 7 & 169 & 2.25 & Low \\
\hline M.15 & $\begin{array}{l}\text { I often have symptoms of high } \\
\text { blood pressure. }\end{array}$ & 68 & 71 & 19 & 7 & 4 & 169 & 1.86 & Low \\
\hline M.16 & $\begin{array}{l}\text { I often feel sudden pain in the } \\
\text { neck. }\end{array}$ & 63 & 65 & 27 & 8 & 6 & 169 & 1.99 & Low \\
\hline \multicolumn{8}{|c|}{ Average } & 2.38 & Low \\
\hline Y.1 & $\begin{array}{l}\text { I work following the applicable } \\
\text { Standard Operating Procedure. }\end{array}$ & 0 & 0 & 2 & 78 & 89 & 167 & 4.51 & Very High \\
\hline Y.2 & $\begin{array}{l}\text { I always complete my duties } \\
\text { without making mistakes. }\end{array}$ & 10 & 38 & 29 & 62 & 30 & 167 & 3.38 & Moderate \\
\hline Y.3 & $\begin{array}{l}\text { I am pleased to complete my } \\
\text { duties on time. }\end{array}$ & 1 & 2 & 8 & 84 & 74 & 167 & 4.35 & Very High \\
\hline Y.4 & $\begin{array}{l}\text { I will not procrastinate in doing } \\
\text { my duties. }\end{array}$ & 0 & 5 & 9 & 80 & 75 & 167 & 4.33 & Very High \\
\hline Y.5 & $\begin{array}{l}\text { Working effectively has become } \\
\text { my habit. }\end{array}$ & 1 & 3 & 14 & 95 & 56 & 167 & 4.20 & Very High \\
\hline Y.6 & $\begin{array}{l}\text { Completing tasks quickly and } \\
\text { precisely has become my } \\
\text { characteristic. }\end{array}$ & 1 & 2 & 23 & 89 & 54 & 167 & 4.14 & High \\
\hline Y.7 & $\begin{array}{l}\text { Each officer has their respective } \\
\text { duties. }\end{array}$ & 2 & 3 & 8 & 84 & 72 & 167 & 4.31 & Very High \\
\hline Y.8 & $\begin{array}{l}\text { I rarely ask my colleagues for } \\
\text { help to complete my duties. }\end{array}$ & 20 & 66 & 31 & 34 & 18 & 167 & 2.79 & Moderate \\
\hline Y.9 & I will do any duty assigned by my & 0 & 3 & 3 & 97 & 66 & & 4.34 & Very High \\
\hline
\end{tabular}




superior.
\begin{tabular}{llllllllll}
\hline Y.10 & I will not be picky about duties. 10 & 15 & 9 & 91 & 44 & & 3.85 & High \\
\hline Average & & & & & & $\mathbf{4 . 0 2}$ & High
\end{tabular}

Annotation: D = Disagree; SD = Somewhat Disagree; SA = Somewhat Agree; A = Agree; EA = Extremely Agree, X1 = Workload; X2 = Work Environment; $\mathrm{M}=$ Work-related Stress; Y = Performance.

The average score of the workload variable was 2.99 (moderate), which indicated that the workload at the Yapen Regency's local police agency was in the "fairly heavy" category. Furthermore, the average score of the work environment variable was 3.86 (high), which indicated that the work environment at the Yapen Regency's local police headquarter was good. Work-related stress got an average score of 2.38, which was categorized in the "low" category. Simultaneously, the performance of officers of the Yapen Regency's local police agency was high, with an average score of 4.02 .

Table 3. Validity and Reliability Tests Results

\begin{tabular}{|c|c|c|c|c|}
\hline Item & R Calculation & Remark & Cronbach's Alpha & Remark \\
\hline X1.1 & 0.548 & Valid & 0.879 & Reliable \\
\hline $\mathrm{X} 1.2$ & 0.673 & Valid & & \\
\hline $\mathrm{X} 1.3$ & 0.677 & Valid & & \\
\hline $\mathrm{X} 1.4$ & 0.634 & Valid & & \\
\hline $\mathrm{X} 1.5$ & 0.665 & Valid & & \\
\hline X1.6 & 0.639 & Valid & & \\
\hline $\mathrm{X} 1.7$ & 0.558 & Valid & & \\
\hline $\mathrm{X} 1.9$ & 0.666 & Valid & & \\
\hline $\mathrm{X} 1.10$ & 0.713 & Valid & & \\
\hline X1.11 & 0.680 & Valid & & \\
\hline $\mathrm{X} 1.12$ & 0.668 & Valid & & \\
\hline $\mathrm{X} 1.13$ & 0.615 & Valid & & \\
\hline $\mathrm{X} 1.14$ & 0.580 & Valid & & \\
\hline $\mathrm{X} 2.2$ & 0.398 & Valid & 0.852 & Reliabel \\
\hline $\mathrm{X} 2.5$ & 0.487 & Valid & & \\
\hline $\mathrm{X} 2.7$ & 0.690 & Valid & & \\
\hline $\mathrm{X} 2.8$ & 0.761 & Valid & & \\
\hline $\mathrm{X} 2.9$ & 0.800 & Valid & & \\
\hline $\mathrm{X} 2.10$ & 0.711 & Valid & & \\
\hline $\mathrm{X} 2.11$ & 0.572 & Valid & & \\
\hline $\mathrm{X} 2.12$ & 0.629 & Valid & & \\
\hline $\mathrm{X} 2.13$ & 0.506 & Valid & & \\
\hline $\mathrm{X} 2.16$ & 0.544 & Valid & & \\
\hline $\mathrm{X} 2.18$ & 0.453 & Valid & & \\
\hline X2.19 & 0.579 & Valid & & \\
\hline $\mathrm{X} 2.22$ & 0.523 & Valid & & \\
\hline $\mathrm{X} 2.24$ & 0.484 & Valid & & \\
\hline M.4 & 0.381 & Valid & 0.787 & Reliabel \\
\hline M.5 & 0.472 & Valid & & \\
\hline M.6 & 0.465 & Valid & & \\
\hline M.7 & 0.600 & Valid & & \\
\hline M.8 & 0.688 & Valid & & \\
\hline M.9 & 0.588 & Valid & & \\
\hline M.10 & 0.486 & Valid & & \\
\hline M.11 & 0.620 & Valid & & \\
\hline M.12 & 0.459 & Valid & & \\
\hline
\end{tabular}




\begin{tabular}{lllll} 
M.13 & 0.635 & Valid & & \\
M.14 & 0.632 & Valid & & \\
M.15 & 0.470 & Valid & & \\
M.16 & 0.450 & Valid & & \\
\hline Y.1 & 0.570 & Valid & 0.798 & Reliabel \\
Y.2 & 0.613 & Valid & & \\
Y.3 & 0.655 & Valid & & \\
Y.4 & 0.625 & Valid & & \\
Y.5 & 0.710 & Valid & & \\
Y.6 & 0.671 & Valid & & \\
Y.7 & 0.514 & Valid & & \\
Y.8 & 0.622 & Valid & & \\
Y.9 & 0.665 & Valid & & \\
Y.10 & 0.571 & Valid & & \\
\hline
\end{tabular}

The validity test was conducted to determine whether or not the questionnaire statement was valid. The measuring instrument used was the product-moment by considering r-statistic. Based on the $5 \%$ significance level with $\mathrm{N}=169$, the obtained critical $\mathrm{r}$ value = 0.1501 (Ghozali, 2018). The results of the validity test in Table 3 showed that all statements had an r-statistic greater than the critical value of 0.1501 , so it can be said that all statements were valid. Also, a reliability test was conducted by considering Cronbach's alpha value. The results of data testing indicated that all variables had Cronbach's alpha value greater than 0.6 so that all variables were declared reliable.

Table 4. Classical Assumption Test Results

\begin{tabular}{ccccccc}
\hline \multicolumn{2}{c}{ Normality Test } & \multicolumn{3}{c}{ Multicollinearity Test } & \multicolumn{2}{c}{$\begin{array}{c}\text { Heteroscedasticity } \\
\text { Test }\end{array}$} \\
\hline \begin{tabular}{c} 
Kolmogorov-Smirnov $\begin{array}{c}\text { Nest } \\
\text { Test }\end{array}$ \\
\multirow{3}{*}{0.048}
\end{tabular} & $\begin{array}{c}\text { Asymp. } \\
\text { Sig }\end{array}$ & Variable & Tolerance & VIF & p-value & Threshold \\
\hline \multirow{2}{*}{0.200} & $\mathrm{X} 1$ & 0.897 & 1.115 & 0.350 & 0.05 \\
\cline { 3 - 7 } & & $\mathrm{X} 2$ & 0.901 & 1.110 & 0.967 & 0.05 \\
\cline { 3 - 7 } & & $\mathrm{X} 3$ & 0.944 & 1.060 & 0.173 & 0.05 \\
\hline
\end{tabular}

This study employed the classical assumption tests-the test to determine whether there was a disturbance or not in the observed data. There were residual normality, multicollinearity, and heteroscedasticity. The normality test is an essential requirement in testing the statistical significance of the regression coefficient. If the regression model is not normally distributed, the conclusions from the regression results are still doubted. According to Table 4, the results of the normality test conducted showed the Asymp. Sig value of 0.200 , more significant than 0.05 . This result meant that the data were normally distributed.

Then, the next test was the multicollinearity test - this test to see whether there was multicollinearity or not in the research data. The test results in Table 4 showed that all independent variables had a tolerance value of greater than 0.1 and a VIF value of less than 10 , so it meant that the data results of each independent variable did not experience multicollinearity. Furthermore, the final test was the heteroscedasticity test-this test determined whether there was an inequality of residuals variants from one observation to another. The result was that the significance value of the three independent variables was more significant than 0.05 , meaning that there was no heteroscedasticity in the regression model. 
Table 5. First Regression Test Results

\begin{tabular}{|c|c|c|c|c|c|c|}
\hline \multirow{2}{*}{\multicolumn{2}{|c|}{ Model }} & \multicolumn{5}{|c|}{ Standardized } \\
\hline & & B & Std. Error & Beta & $\mathrm{t}$ & Sig. \\
\hline 1 & (Constant) & 34.603 & 3.860 & & 8.965 & .000 \\
\hline & Workload & 142 & .055 & 201 & 2.570 & .011 \\
\hline & Work Environment & -.169 & .070 & -.190 & -2.429 & .016 \\
\hline
\end{tabular}

a. Dependent Variable: Work-related Stress

Table 6. Second Regression Test Results

\begin{tabular}{|c|c|c|c|c|c|c|}
\hline \multirow{2}{*}{\multicolumn{2}{|c|}{ Model }} & \multicolumn{2}{|c|}{$\begin{array}{c}\text { Unstandardized } \\
\text { Coefficients }\end{array}$} & \multirow{2}{*}{$\begin{array}{c}\text { Standardized } \\
\text { Coefficients } \\
\text { Beta }\end{array}$} & \multirow[t]{2}{*}{$\mathbf{t}$} & \multirow[t]{2}{*}{ Sig. } \\
\hline & & B & Std. Error & & & \\
\hline \multirow[t]{4}{*}{1} & (Constant) & 27.487 & 2.927 & & 9.390 & .001 \\
\hline & Workload & .070 & .035 & .140 & 2.004 & .047 \\
\hline & Work Environment & .263 & .044 & .417 & 5.969 & .000 \\
\hline & Work-related Stress & -.138 & .048 & -.195 & -2.854 & .005 \\
\hline
\end{tabular}

a. Dependent V ariable: Performance

The regression test was conducted twice. The results of the first regression test showed that workload had a positive and significant influence on work-related stress with a tstatistic of 2.570, more significant than 1.97 (t-table), and a significance of $0.011<0.05$. Thus, the first hypothesis is accepted. The heavier the workload the employee has, the higher their work-related stress becomes. The workload of police officers of Yapen Regency's local police agency would increase stress at the workplace. The results of this research were in line with research conducted by Arifi et al. (2019) and Sinambela (2020). Workload positively influences work-related stress in the employee, which means that the heavy workload allocated by the company to employees can cause stress for employees (Christy \& Priartini, 2019). The workload indicators that indicated a heavy workload were the number of duties in the previous month and the officers' responsibilities, making the officers have sleep difficulty.

The work environment had a negative and significant influence on work-related stress, and therefore, the second hypothesis is accepted. This result can be seen from the tstatistic of -2.429, which was more significant than 1.97 ( $\mathrm{t}$-table), and the significance value of $0.016<0.05$. This research supported previous research conducted by Desa et al. (2018), Hornsby et al. (2009), and Manaf et al. (2019). The work environment of the Yapen Regency's local police agency was good. It was indicated by the statements with the highest score, namely, work atmosphere that supported work completion, suitable air temperature and lighting, and nothings that need to be feared by officers in doing their duties. The better and more conducive the work environment is at the Yapen Regency's local police agency, the less stress the Yapen Regency's local police officers have.

Furthermore, the results of the second regression test in Table 6 showed that workload had a positive and significant influence on performance. This result was reflected in the t-statistic value of $2.004>1.97$ and significance value of $0.047<0.05$. Therefore, the third hypothesis is rejected. These results did not support the research of Huyghebaert et al. (2018) and Ngatimun et al. (2019), which discovered that workload had a negative and significant influence on performance. However, this research was in line with Munandar et al. (2018), which discovered that an increase in employee workload would be able to encourage improved performance. 
Then, the fourth hypothesis is accepted. The work environment was found to have a positive and significant influence on performance. This finding was indicated by the t-statistic value of $5.969>1.97$ and significance value of $0.000<0.05$. The results of this research were in line with research conducted by Handayani (2019) and Rorong (2016), which found that work environment had a positive and significant influence on performance. A good and conducive working environment at the Yapen Regency's local police agency will support the officers in doing their duties and ultimately improve performance. Members of the organization who are in a relatively good work environment will tend to feel happy and comfortable in doing their work compared to employees who are in an unfavorable work environment (McCoy, 2002).

Work-related stress had a negative and significant effect on performance, as seen from the t-statistic of $-2.854>1.97$ and significance of $0.005<0.05$. Thus, the fifth hypothesis is accepted. These results supported the research of Alkubaisi (2015), Ngatimun et al. (2019), and Shahriari et al. (2013), which discovered a negative and significant correlation between work-related stress and performance. Based on the respondents' responses, the level of workrelated stress of Yapen Regency's local police officers was low, so that it might improve their performance.

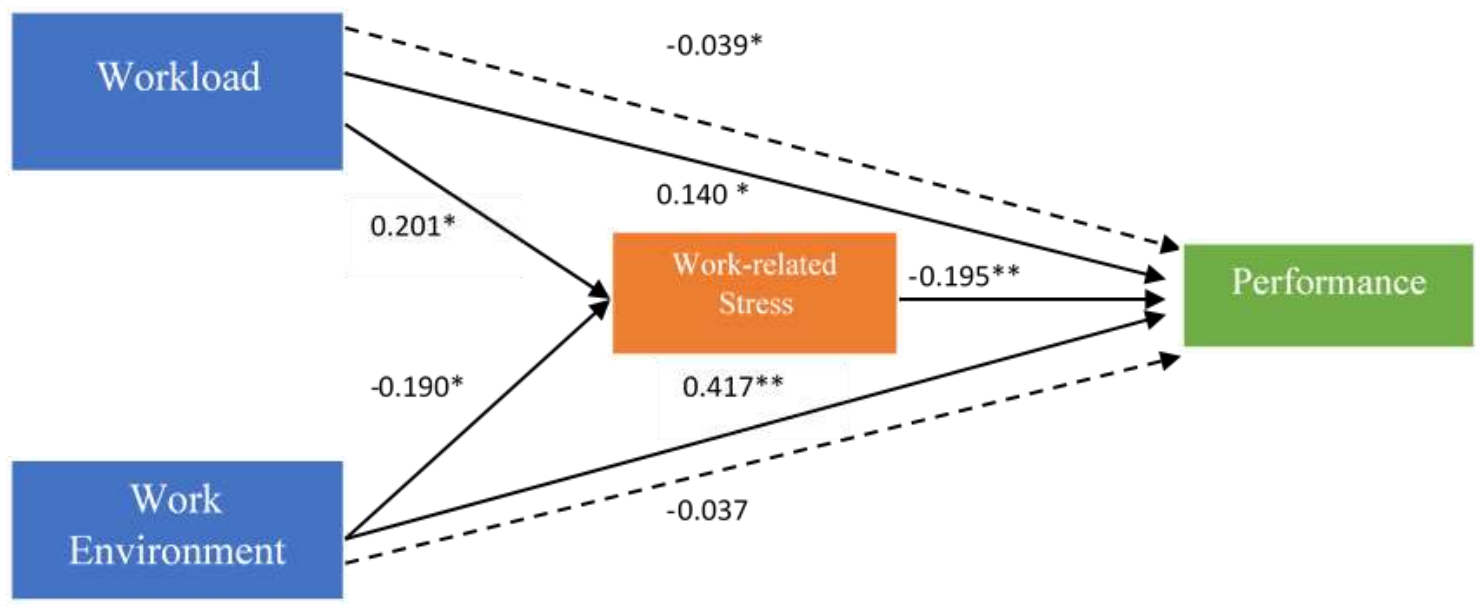

Annotation: $* \mathrm{p}<0.05 * * \mathrm{p}<0.01$ (one-tailed test)

Figure 2. Hypothesis Testing Results

Table 7. Mediation Analysis of Work-related Stress in the Workload-Performance Relationship

\begin{tabular}{clccc}
\hline \multirow{2}{*}{ Model } & \multicolumn{1}{c}{ Relationship } & $\begin{array}{c}\text { Standardized } \\
\text { Estimate }\end{array}$ & $\begin{array}{c}\text { t- } \\
\text { statistic }\end{array}$ & Sobel Test \\
\hline 1 & Workload - Performance & $0.1094^{* *}$ & 2.8967 & Supported \\
2 & Workload - Work-related Stress & $0.1070^{*}$ & 1.9801 & \\
& Workload - Performance & $0.1299^{* *}$ & 3.5230 & \\
& Work-related Stress - Performance & $-0.1913^{* *}$ & -3.6648 & \\
\hline
\end{tabular}

Annotation: ${ }^{*} \mathrm{p}<0.05{ }^{*} \mathrm{p}<0.01$ (one-tailed test)

The results of the research on all hypotheses are presented in Figure 2. The sixth hypothesis, which states that work-related stress mediates the relationship between workload and performance of officers of the Yapen Regency's local police, is accepted. The results of the mediation test, which were obtained with PROCESS macro, are presented in Table 7 and showed that work-related stress could mediate the relationship between workload and performance. This mediating effect was significant with a 95\% confidence interval (BootLLCI 
$=-0.0557$, BootULCI $=0.0043)$, which did not include zero values. The indirect influence of workload on performance mediated by work-related stress was $-0.039(0.201 \mathrm{x}-0.195)$. The results of this research were in line with previous research conducted by Shabbir and Naqvi (2017), and Susiarty et al. (2019). The workload of the officers at Yapen Regency's local police headquarter was low, so their work-related stress was also low, and ultimately, it might improve their performance.

Table 8. Mediation Analysis of Work-related Stress in the Work Environment-Performance Relationship

\begin{tabular}{|c|c|c|c|c|}
\hline Model & Relationship & $\begin{array}{c}\text { Standardized } \\
\text { Estimate }\end{array}$ & $\begin{array}{c}\mathrm{t}- \\
\text { statistic }\end{array}$ & Sobel Test \\
\hline 1 & Work Environment - Performance & $0.3034 * *$ & 7.0681 & Not \\
\hline & Work Environment - Work-related Stress & -0.1228 & -1.7950 & Supported \\
\hline & Work Environment - Performance & $0.2888^{* *}$ & 6.7665 & \\
\hline & Work-related Stress - Performance & $-0.1189 *$ & -2.4876 & \\
\hline
\end{tabular}

Annotation: ${ }^{*} \mathrm{p}<0.05{ }^{* *} \mathrm{p}<0.01$ (one-tailed test)

The seventh hypothesis, which states that work-related stress mediates the relationship between the work environment and the performance of officers of Yapen Regency's local police, is rejected. It was based on the mediation analysis using PROCESS macro. The results showed (Table 8 ) that the mediation analysis did not meet all the conditions. It was not in line with previous research conducted by Susiarty et al. (2019) and Khuong and Yen (2016).

\section{Conclusion}

The results of this research can be concluded as follows: firstly, the workload had a positive and significant influence on work-related stress. It meant that the heavier the workload assigned to police officers of the Yapen Regency's local police, the work-related stress experienced by the officers would increase. Secondly, the work environment had a negative and significant influence on work-related stress. It meant that a good work environment would reduce the level of work-related stress. Thirdly, workload and work environment had a positive and significant influence on police officers' performance. Fourthly, work-related stress had a negative and significant influence on the performance of the police officers. It implies that the lower the level of work-related stress of the officers is, the better their performance will be. Fifthly, work-related stress could mediate the relationship between workload and performance. Finally, work-related stress could not mediate the relationship between work environment and performance.

Based on the research results, there are several recommendations and implications for the Yapen Regency's local police agency. It is better if the workload assigned is reduced and the work environment is upgraded by providing an adequate workspace that will support the officers in completing their work. A relatively sufficient workload, a supportive work environment, and a low level of work-related stress will increase police officers' performance in doing their duties in the Yapen Regency's local police agency. Future researchers may consider special units as an essential aspect in analyzing the performance of police officers at the Yapen Regency's local police agency headquarter. Future research may analyze different levels of performance of police officers who work outdoor and those who work indoor in the office setting by adding work motivation as a variable. 


\section{References}

Abdiyanto \& Warokka, A. (2015). Priority-Driven Budgeting Policy and Regional Inequality: Does Economic Structure Transformation Really Perform as Intervening Variable? Journal of Economics Studies and Research, 2015, c1-18. http://dx.doi.org/10.5171/2015.216353

Ackah, D. (2015). The Impact of Motivation on Employee Performance in the Manufacturing Industry in Ghana. Global Journal of Management Studies and Researches, 1(5), 291310. https://doi.org/10.24924/ijabm/2015.11/v3.iss2/29.45

Ahmed, A., \& Ramzan, M. (2013). Effects of job stress on employees job performance: A study on banking sector of Pakistan. IOSR Journal of Business and Management, 11(6), 61-68.

Al-Mohannadi, A., \& Capel, S. (2007). Stress in physical education teachers in Qatar. Social Psychology of Education, 10(1), 55-75.

Alkubaisi, M. M. (2015). How can Stress Affect Your Work Performance? Quantitative Field Study on Qatari Banking Sector. Business and Management Research, 4(1), 99-109. https://doi.org/10.5430/bmr.v4n1p99

Arafat, M. Y., Warokka, A., Abdullah, H. H., \& Septian, R. R. (2012). The triple bottom line effect on emerging market companies: A test of corporate social responsibility and firm value relationship. Journal of Southeast Asian Research, 2012(2012), 1-15.

Arif, S., et al. (2019). Influence of Leadership, Organizational Culture, Work Motivation, and Job Satisfaction of Performance Principles of Senior High School in Medan City. Budapest International Research and Critics Institute-Journal (BIRCI-Journal). P. 239-254

Arnetz, B. B., Arble, E., Backman, L., Lynch, A., \& Lublin, A. (2013). Assessment of a prevention program for work-related stress among urban police officers. International archives of occupational and environmental health, 86(1), 79-88.

Huff, J. (2020). Examining Variation in Police Discretion: The Impact of Context and BodyWorn Cameras on Officer Behavior (Doctoral dissertation, Arizona State University).

Campbell, J. P., \& Wiernik, B. M. (2015). The Modeling and Assessment of Work Performance. Annual Review of Organizational Psychology and Organizational Behavior, 2(August), 47-74. https://doi.org/10.1146/annurev-orgpsych-032414-111427

Chen, Y. F. (2009). Job stress and performance: A study of police officers in central Taiwan. Social Behavior and Personality: an international journal, 37(10), 1341-1356.

Cherrington, D. J. (1989). The Management of Individual and Organizational Performance: Instructor's Manual for Organizational Behavior. Allyn and Bacon.

Christy, M. Y. P., \& Priartini, P. S. (2019). Role of work stress and organizational commitments in educating workload effect on intention to quit. International Research Journal of Management, IT and Social Sciences, 6(4), 8-16.

Dalbokova, D., \& Krzyzanowski, M. (2002). Environmental health indicators: Development of a methodology for the WHO European region. Statistical Journal of the United Nations Economic Commission for Europe, 19(1-2 SPEC.), 93-103. https://doi.org/10.3233/sju-2002-191-209

Davies, S. G., Meliala, A., \& Buttle, J. (2016). Gangnam Style versus Eye of the Tiger: people, police and procedural justice in Indonesia. Policing and society, 26(4), 453-474.

Desa, N. M., Khoon, T. L., \& Asaari, M. H. A. H. (2018). Work Stress Toward Work Environment, Management Support, and Employee Satisfaction among Employees of Public Organizations. International Journal of Asian Social Science, 8(1), 1-11. https://doi.org/10.18488/journal.1.2018.81.1.11

Fan, J., \& Smith, A. P. (2017). The impact of workload and fatigue on performance. International symposium on human mental Workload: Models and applications, 90-105. 
Handayani, R. (2019). The Effect of Discipline and Work Environment on Employee Performance in Ciputat Sector Police. PINISI Discretion Review, 3(2), 125. https://doi.org/10.26858/pdr.v3i2.13258

Handoko, T. H. (2014). Manajemen Personalia dan Sumber Daya Manusia. Yogyakarta: BPFE.

Hartinah, S., Suharso, P., Umam, R., Syazali, M., Lestari, B., Roslina, R., \& Jermsittiparsert, K. (2020). Retracted: Teacher's performance management: The role of principal's leadership, work environment and motivation in Tegal City, Indonesia. Management Science Letters, 10(1), 235-246.

Hornsby, J. S., Kuratko, D. F., Shepherd, D. A., \& Bott, J. P. (2009). Managers' corporate entrepreneurial actions: Examining perception and position. Journal of Business Venturing, 24(3), 236-247. https://doi.org/10.1016/j.jbusvent.2008.03.002

Huyghebaert, T., Gillet, N., Beltou, N., Tellier, F., \& Fouquereau, E. (2018). Effects of Workload on teachers' functioning: A moderated mediation model including sleeping problems and overcommitment. Stress and Health, 34(5), 601-611. https://doi.org/10.1002/smi.2820

Im, T. (2009). An exploratory study of time stress and its causes among government employees. Public Administration Review, 69(1), 104-115.

Jones, T. E. (2019). Key Factors That Influence Job Performance: The Performance Pathway Model. Training Industry.

Khuong, M. N., \& Yen, V. H. (2016). Investigate the effects of job stress on employee job performance--a case study at Dong Xuyen industrial zone, Vietnam. International Journal of Trade, Economics and Finance, 7(2), 31.

Manaf, A., Matin, M., \& Zulaikha, S. (2019). Effect of Work Environment and Work Loads on the Performance of Police Educators in Sepolwan Lemdiklat Polri. International Journal for Educational and Vocational Studies, 1(5), 461-466. https://doi.org/10.29103/ijevs.v1i5.1714

McCoy, J. M. (2002). Work environments. Handbook of environmental psychology, 443-460.

Munandar, A., Musnadi, S., \& Sulaiman, S. (2018). The Effect of Work Stress, Work Load and Work Environment on Job Satisfaction And It's Implication on The Employee Performance of Aceh Investment And One Stop Services Agency. Proceeding of the First International Graduate Conference (IGC) On Innovation, Creativity, Digital, \& Technopreneurship for Sustainable Development in Conjunction with The 6th Roundtable for Indonesian Entrepreneurship Educators 2018.

Murali, S. B., Basit, A., \& Hassan, Z. (2017). Impact of Job Stress on Employee Performance. International Journal of Accounting, Business \& Management, 5(2), 13-33.

Ngatimun, Sanusi, A., \& Manan, A. (2019). The Effect of Workload, Work Stress , and Emotional Intelligence towards Teacher Performance through Organizational Commitment. IOSR Journal of Business and Management, 21(8), 63-72. https://doi.org/10.9790/487X-2108026372

Oron-Gilad, T., Szalma, J. L., Stafford, S. C., \& Hancock, P. A. (2008). The workload and performance relationship in the real world: A study of police officers in a field shooting exercise. International Journal of Occupational Safety and Ergonomics, 14(2), 119-131.

Rorong, S. V. (2016). The impact of physical work environment toward employee performance at PT. Bank Negara Indonesia Manado Regional Office. Journal EMBA, 4(1), 441-450.

Saragih, S.L., and Ananda, R. (The Relation between the Empowerment of Teacher's Meeting and Achievement Motivation on Teacher Performances in MTsN 3 (Islamic Junior High School 3) Simalungun. Budapest International Research and Critics in Linguistics and Education (BirLE) Journal. P. 37-51.

Schmidt, F. L. (2002). The role of general cognitive ability and job performance: Why there cannot be a debate. Human performance, 15(1-2), 187-210.

Shabbir, B., \& Naqvi, R. (2017). Impact of Workload and Job Complexity on Employee Job Performance with the Moderating Role of Social Support and Mediating Role of Job 
Stress: A Study of Travel agencies in Rawalpindi, Islamabad and AJK. Journal of Accounting \& Marketing, 6(1), 1-7. https://doi.org/10.4172/2168-9601.1000214

Shahriari, J. ., Mehdi, M., Pirhossein, K., \& Jasmid, M. (2013). Influential Factors on Job Stress and Its Effect on The Employee's Performance among Bank Sepah Branches in Tehran. Journal OF Fundamental and Applied Life Sciences, 3(3), 446-451.

Sharma, S. (2015). Occupational stress in the armed forces: An Indian army perspective. IIMB Management Review, 27(3), 185-195.

Sinambela, S. (2020). The Effect of Workload on Job Stress, Work Motivation, and Employee Performance. International Journal of Psychosocial Rehabilitation, 24(4).

Susiarty, A., Suparman, L., \& Suryatni, M. (2019). the Effect of Workload and Work Environment on Job Stress and Its Impact on the Performance of Nurse Inpatient Rooms At Mataram City General Hospital. Scientific Research Journal, 7(6), 32-40. https://doi.org/10.31364/scirj/v7.i6.2019.p0619661

Vischer, J. C. (2008). Towards an environmental psychology of workspace: how people are affected by environments for work. Architectural science review, 51(2), 97-108.

Waal, A. de. (2018). Success factors of high performance organization transformations. Measuring Business Excellence, 22(4), 375-390. https://doi.org/10.1108/mbe-082018-0055

Warokka, A., \& Febrilia, I. (2015). Work-family conflict and job performance: Lesson from a Southeast Asian emerging market. Journal of Southeast Asian Research, 2015(2015), $1-14$. 